\title{
Emission Characterization of Diesel Engine Run on Coconut Oil Biodiesel its Blends and Diesel
}

\author{
*1NICHOLAS, A. MUSA; GEORGINA, M. TERAN; SARAKI, A. YAMAN ${ }^{3}$ \\ ${ }^{1,2,3}$ Department of Mechanical Engineering, \\ Federal University of Technology, Minna, Niger State, Nigeria. \\ $1 *$ Corresponding Author: Madonick1@yahoo.com
}

\begin{abstract}
The use of biodiesel in running diesel has been called for, with a view to mitigating the environmental pollution, depletion, cost and scarcity associated with the use diesel in running diesel engine. So the need to characterize the emissions from these biodiesel, cannot be overemphasized, hence this paper presents the evaluation of the emissions of particulate matter $(\mathrm{PM})$, carbon monoxide $(\mathrm{CO})$, hydrocarbon $(\mathrm{HC})$ and oxides of nitrogen $\left(\mathrm{NO}_{\mathrm{X}}\right)$ from diesel engine run on coconut oil biodiesel, its blends and diesel for comparison. The result of the evaluation showed that $\mathrm{NO}_{\mathrm{X}}$ emission increased with increase in percentage of the biodiesel in the blend, while PM, CO, HC decreased with increase in the percentage biodiesel in the blend. In comparison with diesel, diesel has the least emission of $\mathrm{NO}_{\mathrm{X}}$ and the highest emission of PM, CO and HC. ( ) JASEM
\end{abstract}

http://dx.doi.org/10.4314/jasem.v20i2.10

KEYWORDS: Diesel engine, diesel, coconut oil biodiesel, blends, emissions

Introduction

It is quite common nowadays to learn that every country is in the race to find suitable and affordable alternative fuel options for diesel engine (Savariraj et al, 2013). The quest for finding alternative fuel options for diesel engine stemmed from the depletion, dwindling price and the environmental pollution associated with the use of diesel. Kantharaju et al(2015) opined that the air we breathe is proven to be unhealthy, the various emission from the automobile exhaust like $\mathrm{CO}, \mathrm{HC}, \mathrm{NO}_{\mathrm{X}}$, particulate matters, soot etc., are highly harmful for human health and apart from that, animals and plants are also facing a negative impact by emission caused by automobiles. Automobile exhaust emission has also actively participated in increasing global warming. According to Gopal and Karupparaj (2015), finding suitable sustainable fuel alternatives has become a high priority for many countries. Chiatti et al (2014) asserted that increasing attention has been devoted to the use of biodiesel fuel in internal combustion diesel engine due to its positive attributes as compared to the other types of fuel: e.g., being a renewable source, nonpetroleum-based, with lower carbon monoxide, hydrocarbon, and particulate matter emissions. Xue et $\mathrm{al}(2011)$ remarked that the use of biodiesel leads to the substantial reduction in $\mathrm{PM}, \mathrm{HC}$ and $\mathrm{CO}$ emissions accompanying with the imperceptible power loss, the increase in fuel consumption and the increase in NOx emission on conventional diesel engines with no or fewer modification. Maharana and Chnadra(2015), however stated that biodiesel can be used in the existing engine without any modifications. Bio-diesel, by the name, is a clean burning alternative fuel for diesel which is distilled from renewable sources such as vegetable oils, animal fats and waste bio products. It is considered to be more environmental friendly compared to existing fossil fuels which is a limited resource (Manorathna and Nanayakkara, 2011). There are numerous types of bio-diesel available today that come from various sources. Some common oils that are used for fuel as biodiesel are olive kernel oil, corn oil, sunflower oil, soybean oil, cottonseed oil, palm oil, rapeseed oil, and their methyl ester derivatives (Rakapolous, et al., 2006\} cited by Brendan(2010). Biodiesel has become an interesting alternative to be used in diesel engine which is due to the similar properties to the conventional fossil diesel fuel in terms of power and torque and none or very minor of engine modification is required (Belaid et al, 2011) cited by Islam et al, (2014). Moreover, the biodiesel has a few special features which are biodegradability and being much more environmentally friendly compared to the conventional fossil diesel (Janaun and Ellis, 2010). A lot of work has been done partly or wholly by many researchers on emissions and performance of diesel engine running on biodiesel from edible and non-edible plants and its blends. Musa et al (2016) remarked that coconut oil and biodiesel produced from it have been characterized and from the results obtained and discussed, it became very evident that 
coconut oil is a good feedstock for biodiesel production and the biodiesel can be used in convectional diesel engine without modification because of close fuel properties.

The aim of the study is to characterize the emissions from diesel engine run on coconut oil biodiesel and its blend in comparison with diesel.

\section{MATERIALS AND METHODS}

The fuel materials used for this study include diesel fuel, biodiesel produced from coconut oil by Teran and Saraki(2015), whose fuel properties have been determined by Musa et al, (2016) and the blends of the biodiesel. The test rig used for this study includes GD411 diesel Honda 9.0 an air cooled, 4cycles, single cylinder and 9 horse power engine manufactured by Honda Motor Company, Japan, coupled to dynamometer, equipped with sensors, data acquisition and digital display systems. A total gas analyzer (Motorscan 8050) made in Italy which can measure the concentration of the emission of carbon monoxide (CO), hydrocarbon (HC) and nitrogen oxides (NOx) was employed.

Experimental Procedure: According to Dharmadhikari et al, 2012, the blend of biodiesel and diesel has density close to that of mineral diesel and the biodiesel can be directly mixed with diesel fuel. So, Blends of coconut oil biodiesel and diesel fuel were produced in the ratio of 10:90, 20:80, 30:70, 40:60 and 50:50 by volume, denoted by B10, B20, B30, B40 and B50 respectively. The engine was made to run for 30 minutes in line with the work of Savariraj et al(2013) wisth $100 \%$ diesel fuel denoted by B0 as base fuel or reference fuel at constant speed of $1000 \mathrm{rpm}$ which was measured by digital Tachometer. The engine load was applied by employing dynamometer that was coupled to it. The fuel consumption rate was measured using a glass burette and stopwatch. A total gas analyzer (Motorscan 8050) made in Italy was used to measure the concentration of the emission of carbon monoxide (CO), hydrocarbon (HC) and nitrogen oxides (NOx) from the engine through the exhaust as shown in plate I. The particulate matter (PM) was measured by adopting Akeredolu and Oyawale (2000), method where a re-weighed $2 \mu \mathrm{m}$ cellulose filter paper was held in place by a filter holder to trap the particulate matter. After completing the experiment with $100 \%$ diesel denoted by B0, the engine was allowed to run with $100 \%$ biodiesel denoted by B100 and biodiesel blends that is B10, B20, B30, B40, and B50 respectively. Each test was repeated five times and the arithmetic means of the readings or observations were taken as the results and depicted in Table 1.

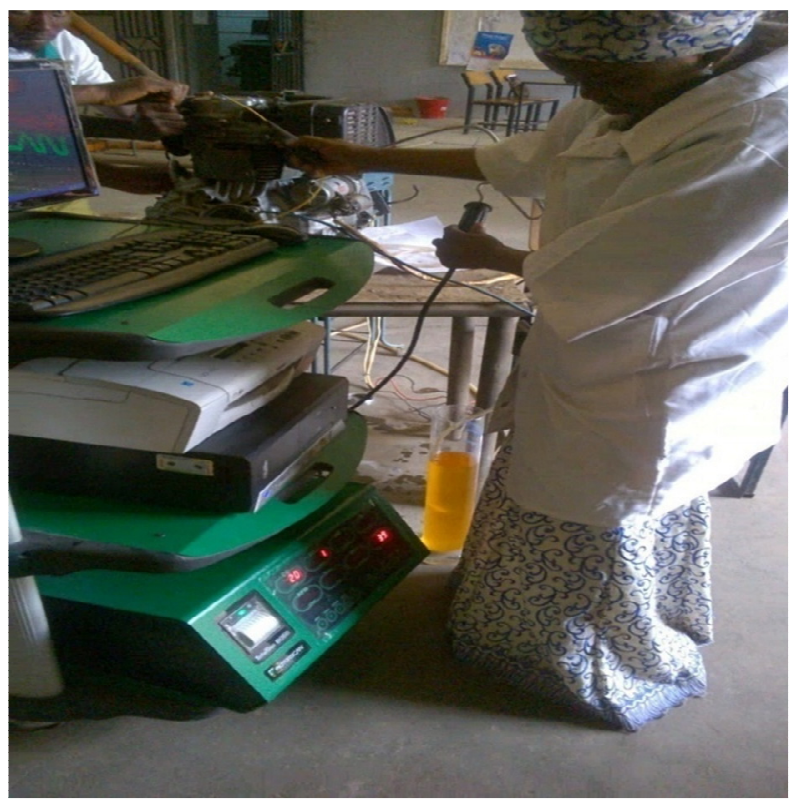

Plate I: Engine exhaust gas measurement (Motorscan 8050 gas analyzer).

\section{RESULTS AND DISCUSSION}

Experimental results obtained from the diesel engine when it was run on diesel, the coconut oil biodiesel and its blends are shown in Table 1.

Table 1: Emissions from the diesel engine run on diesel, coconut oil biodiesel and its blends and the fuel consumption rate.

\begin{tabular}{lcccccl}
\hline Fuel & PM\% & CO\% & HC\% & NO & Speed & $\begin{array}{l}\text { Fuel Consumption } \\
\text { (ml/min) }\end{array}$ \\
\hline Diesel(B0) & 10 & 2 & 3 & 2 & 1000 & 50 \\
B100 & -47 & -48 & -67 & 31 & 1000 & 24.75 \\
B50 & -40 & -41 & -51 & 10 & 1000 & 25 \\
B40 & -34 & -34 & -40 & 8 & 1000 & 25.51 \\
B30 & -23 & -22 & -31 & 7 & 1000 & 38.46 \\
B20 & -12 & -12 & -20 & 6 & 1000 & 43.48 \\
B10 & -7 & -8 & -12 & 4 & 1000 & 45.46 \\
& & & & & & \\
\hline
\end{tabular}


The negative sign in the emissions of PM, CO and HC in Table 1 indicates the reduction of the

percentage change in emission. It can be seen from Table 1 that $\mathrm{NO}_{\mathrm{X}}$ emission increased with increase in the percentage of biodiesel in the blend, while PM, CO and $\mathrm{HC}$ decreased with increase in the percentage of bio diesel in the blend and diesel has the least emission of $\mathrm{NO}_{\mathrm{X}}$ and the highest emission of $\mathrm{PM}, \mathrm{CO}$ and $\mathrm{HC}$ when they were respectively used to run the diesel engine. The decrease of PM and $\mathrm{HC}$ is as a result of the additional oxygen content in the fuel, which helps to oxidize these combustion products and improve combustion in the cylinder(Enweremadu and Mbarawa, 2009). On the other hand, the reduction of $\mathrm{CO}$ and $\mathrm{HC}$ is due to the oxygenated fuel of biodiesel, it leads to a more complete combustion( Islam et al,2014)

It is evident in Table 1 that fuel consumption rate of the diesel engine was $50 \mathrm{ml} / \mathrm{min}$ when diesel was solely used to run the engine, while it was $24.75 \mathrm{ml} / \mathrm{min}$ when biodiesel (B100) was solely used to run the engine, which indicates almost 50\% reduction in fuel consumption rate. However the fuel consumption rate increased with decrease in the percentage of biodiesel in the blends.

\section{CONCLUSION}

Emissions of $\mathrm{PM}, \mathrm{CO}, \mathrm{HC}$ and $\mathrm{NO}_{\mathrm{x}}$ from diesel engine run on coconut oil biodiesel, its blends and diesel have been characterized. The following conclusion can be made: emission of $\mathrm{NO}_{\mathrm{X}}$ in the coconut oil biodiesel and its blend is higher than that of diesel. PM, CO and $\mathrm{HC}$ decreased with increase in the percentage of biodiesel in the blend and are higher than those of diesel. Less fuel consumption rate can be achieved for coconut oil biodiesel and its blend compare to diesel when they are used to run diesel engine. Coconut oil biodiesel and its blends can be used to run diesel engine without any modification, since there was no manifestation of any problem when it was used to run the diesel engine.

\section{REFERENCES}

Akeredolu, FA; Oyawale, O C (2000). Monitoring combustion chamber. Journal of the Nigerian Society of Chemical Engineers, :10-12

Brendan, L(2010). Biodiesel Emissions; Characterization of with new instruments based on chassis dynamometer tests. A Thesis Proposal submitted to the Department of Mechanical Engineering, Clarkson University.
Chiatti, G.; Chiavola, O.; Palmieri, F.; Albertini, $\mathrm{S}(2014)$. Combustion and emission Characterisation of biodiesel blends in a city-car engine. Energy Fuels, 28(8): 5076-5085

Dharmadhikari, H M.; Puli Ravi Kumar, S.; Srinivasa, R(2012) Performance and emissions of C.I. engine using blends of biodiesel and diesel at different injection pressures. International Journal of Applied Research in Mechanical Engineering, 2(2): $2231-5950$

Enweremadu, C C.; Mbarawa, M M(2009). Technical aspects of production and analysis of biodiesel from used cooking oil-a review. Renewable and Sustainable Energy Reviews, 13(9) : 2205-2224.

Gopal K N.; Karupparaj R T (2015). Effect of pongamia biodiesel on emission and combustion characteristics of DI compression ignition engine. Ain Shams Engineering Journal, 6(1):297-305.

Islam, M S.; Ahmed, A S.; Islam, A.; Abdul Aziz, S.; Xain L C.; Mridha M(2014). Study on emission and performance of diesel engine using castor biodiesel. Journal of Chemistry,2014:1-7

Janaun, J.; Ellis, N(2010). Perspectives on biodiesel as a sustainable fuel. Renewable and Sustainable Energy Reviews, 14(4): 1312-1320.

Kantharaju, T.; Harish, H.; Subbaramaiah, S. V.; Rajanna, S.; Prakash, G. S(2015).

Performance and emission characterization of waste chicken fat biodiesel as an alternate fuel. International Journal of Emerging Technology and Advanced Engineering, 5(5): 191-200

Maharana ,B L.; Chnadra, H (2015). Evaluation of performance of diesel engine with biodiesel. International Journal of Advanced Engineering Research and Studies :181-183

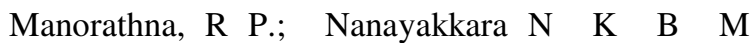
$P(2011)$.Experimental investigation of operating characteristics of bio-diesel on a conventional diesel engine. International Journal of Innovation, Management and Technology, 2(3): 199-203

Musa, N A.; Teran, G M.; Yaman, S A(2016) Characterization of coconut oil and its biodiesel. 
Journal of Scientific Research \& Reports 9(6): 16.

Savariraj, S.; Ganapathy, T.; Saravanan, C G(2013). Performance, emission and combustion characteristics of fish-oil biodiesel engine. European Journal of Applied Engineering and Scientific Research, 2 (3):26-32
Teran, G M.; Yaman, S A(2015). Production of biodiesel from coconut oil to power a diesel engine. Postgraduate Diploma project submitted to postgraduate school, Federal

University of Technology Minna, Nigeria.

Xue, T.; Grift, T E.; Hansen, A(2011). Effect of biodiesel on engine performances and emissions. Renewable and Sustainable Energy Reviews, 15(2011): 1098-1116. 